\title{
Postal censorship of Bosnian public health institutions during the Second World War: The Independent State of Croatia versus Dr. Stanko Sielski
}

\author{
John A. Papalas ${ }^{1}$, Husref Tahirović ${ }^{2}$ \\ ${ }^{1}$ Duke University Medical Center, \\ Department of Pathology. Durham, \\ North Carolina, USA, ${ }^{2}$ Department of \\ Medical Sciences, Academy of Sciences \\ and Arts of Bosnia and Herzegovina \\ Correspondence: \\ husref.tahirovic@untz.ba \\ Tel.:/Fax: + 38735303740 \\ Received: 6 August 2016 \\ Accepted: 9 September 2016 \\ Key words: Postal censorship - Stanko \\ Sielski - History of medicine. \\ This study aims to present evidence of censorship during World War II \\ by the Independent State of Croatia of one of its public health officials, \\ Dr. Stanko Sielski who was a physician trained in epidemiology and \\ public health. During World War II, he directed the Institute for Com- \\ bating Endemic Syphilis in the Bosnian town Banja Luka. The staff un- \\ der his direction consisted solely of Jewish physicians. We analyzed two \\ groups of envelopes either sent by or to Dr. Stanko Sielski during the \\ War and found evidence of censorship only in communications with a \\ Jewish physician dated towards the end of the War. Dr. Stanko Sielski \\ would be posthumously recognized for his efforts to shield his Jew- \\ ish colleagues. Conclusion. The newly available, but still limited data, \\ which we present indicates efforts to censor Dr. Stanko Sielski's postal \\ communications towards the War's end. The censors targeted specifi- \\ cally Dr. Stanko Sielski's correspondences with the Jewish physicians he \\ was protecting. This material highlights the many challenges his public \\ health service experienced during the time of armed conflict.
}

\section{Introduction}

The Independent State of Croatia (ISC) was founded on April 10 $0^{\text {th }}$, 1941, after the invasion of Yugoslavia by the Axis powers and dissolved after the military defeat of Germany in May 1945. It consisted of most of modern-day Croatia and Bosnia and Herzegovina $(\mathrm{BH})$, together with some parts of modern-day Serbia (1). The modern public health infrastructure developed in $\mathrm{BH}$ during the Austro-Hungarian occupation in the later part of the $19^{\text {th }}$ century (2) and continued after the first World War. By the outbreak of World War II in 1941, the ISC had established the Institute for Combating Endemic Syphilis (ICES) in the Bosnian town
Banja Luka. At that time, all of the physicians working there were Jewish. The ICES was founded in order to eradicate the disease in rural Bosnian villages (3). Dr. Stanko Sielski, a talented and dynamic $\mathrm{BH}$ native physician and important ethnographer, served as the head of the ICES from 1941 to 1944 (4). Dr. Stanko Sielski was born and educated in $\mathrm{BH}$, and spent his entire professional career there principally helping the impoverished and sickly rural populations whose misfortunes were compounded by both World Wars (4). Recent and ongoing scholarship has characterized another population assisted by Dr. Stanko Sielski; Jewish physicians practicing in $\mathrm{BH}(4)$. Both the Allies and the 
Axis practiced the censorship of mail during the Second World War. Civil, military and prisoner populations were all monitored to various degrees (5). Censorship of public health institutes throughout Europe at that time is less certain.

This study presents evidence that the ISC censored the communications of Dr. Stanko Sielski, the director of a State public health institute. The timing of the censorship and the persons it is directed against suggest the ISC had begun to suspect the institute of subversion.

\section{The description of State censorship of Dr. Stanko Sielski's communications}

Were the authorities of the ISC suspicious of Dr. Stanko Sielski's motives to shield Jewish doctors from the Holocaust? We would like to present a small piece of evidence which can help to address this question. Currently, there are at least two collections of Dr. Stanko Sielski's envelopes existent from the period of the Second Word War. One group (six envelopes, all addressed to Dr. Stanko Sielski) (6) contains one envelope that bears the postal censor's ("CENZURA", Croatian) mark (Figure 1). The others in this group were not marked (Figure 2).

The second group of ten envelopes is archived in the Section of History of Medicine in the Croatian Academy of Sciences and Arts in Zagreb; the collection includes seven letters that Dr. Stanko Sielski sent to Dr. Vladimir Ćepulić, the head of the Croatian Medical Association, and three in return (7). No letter from the Zagreb collection bares the mark of censorship.

The censored letter was postmarked 1944, which is later than any of the other letters Dr. Stanko Sielski received. Furthermore, the censored letter was sent from Dr. Emil Reich (Figure 1 inset lower right-hand corner), a Jewish physician who worked under Dr. Stanko Sielski at the Institute (8). While this cannot be considered proof, it does indicate that the State had become suspicious of Dr. Stanko Sielski, specifically in his communications with the Jewish doctors

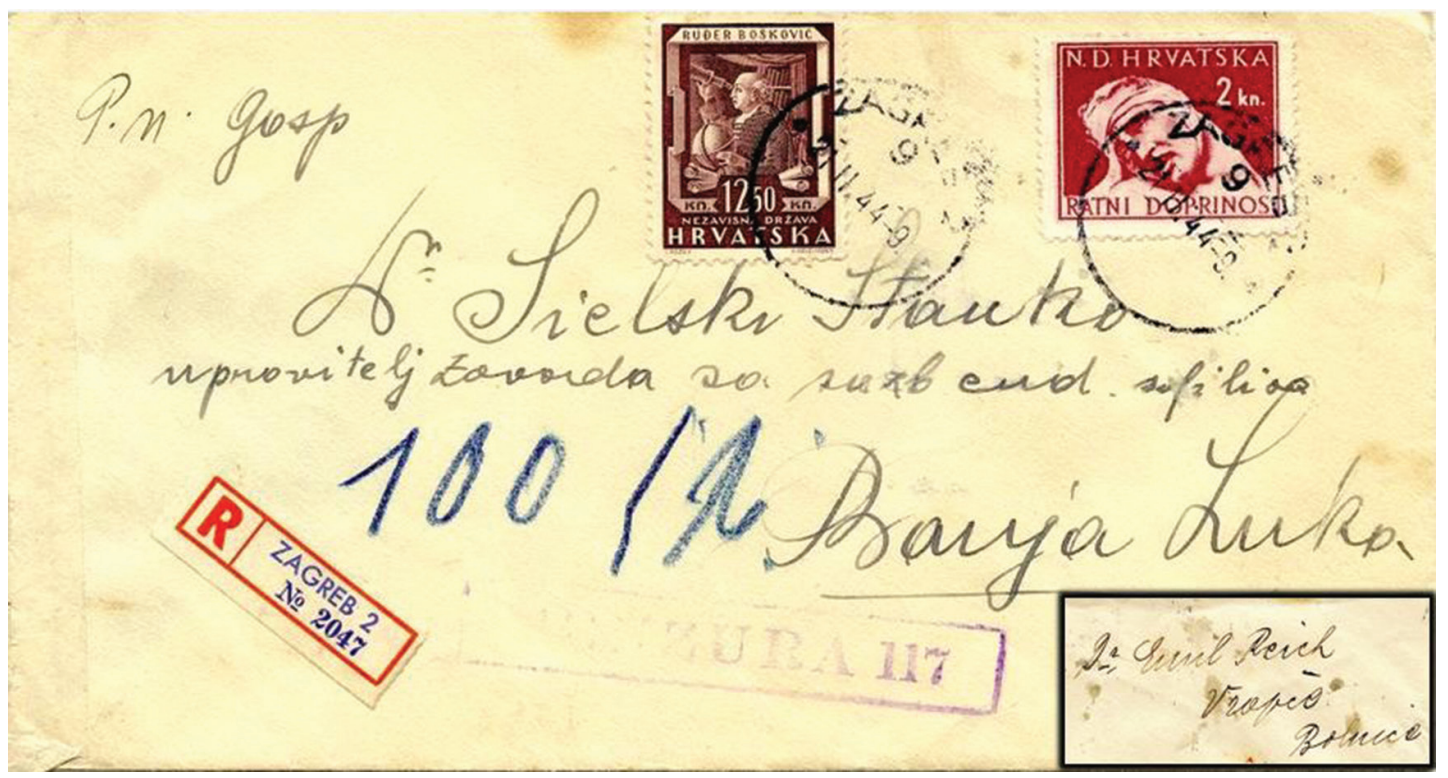

Figure 1 Letter (cover) addressed to Dr. Stanko Sielski with “Censura 117" stamp postmarked 1944. Inset lower right hand corner: Reverse of envelope showing Dr. Emil Reich, Vrapče, Zagreb. 

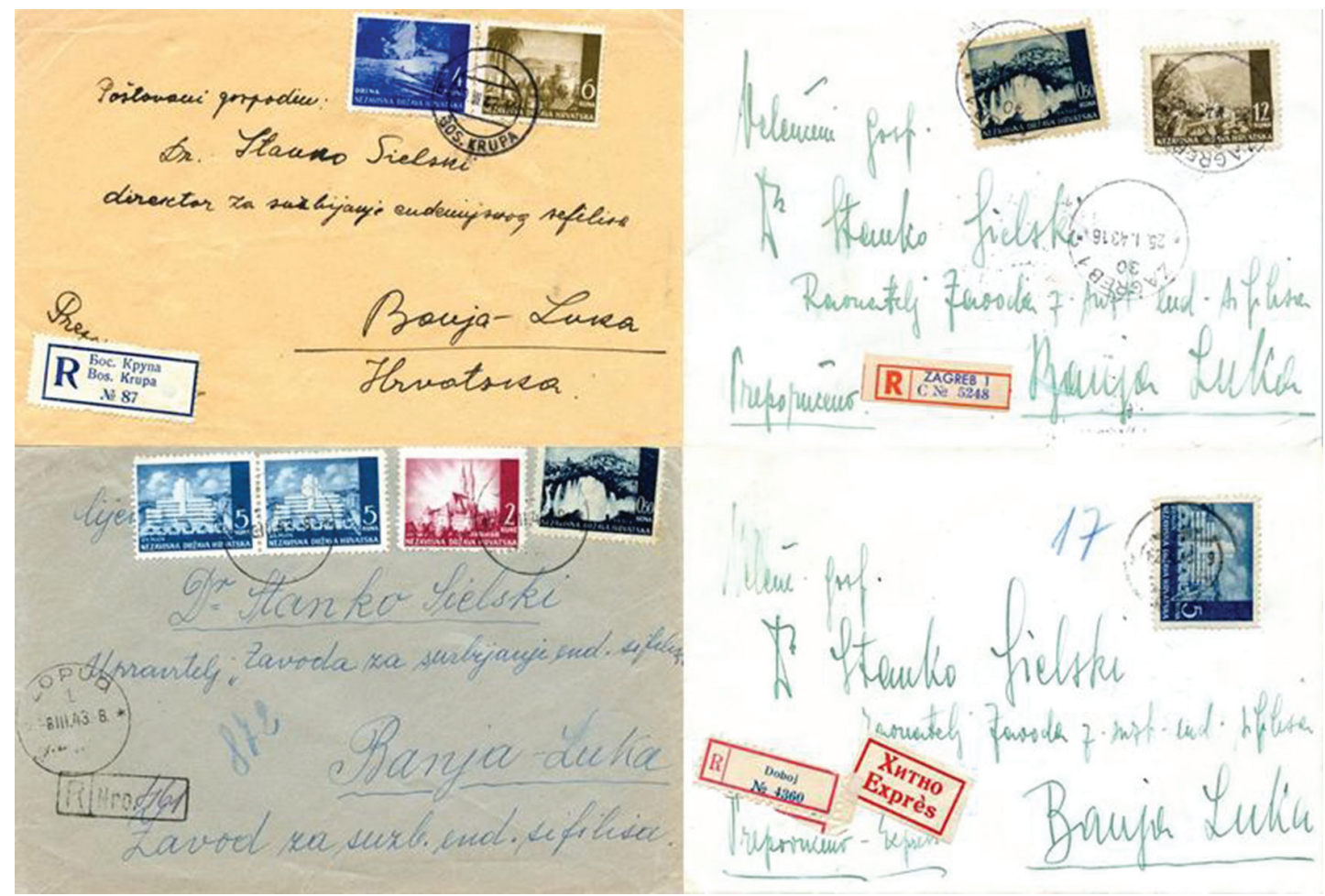

Figure 2 Composite image of 4 uncensored letters addressed to Dr. Stanko Sielski with dates ranging from 1942 (upper left), 1943 (upper right), 1943 (bottom right) and 1943 (bottom left).

whom he directed. Unfortunately, we lack the envelopes contents but speculate that it may have been related to Dr. Emil Reich's recent hospitalization (9).

The censor's suspicion about Dr. Stanko Sielski most likely was related to his efforts to help his Jewish colleagues. Due to Dr. Husref Tahirovićs (an author) advocacy, Dr. Stanko Sielski's efforts were recognized posthumously by the State of Israel who awarded him the Righteous Among Nations. This award is given to non-Jewish peoples whose efforts contributed to saving Jewish lives. Dr. Stanko Sielski is one of only a few physicians to receive the honor (10).

\section{Conclusion}

Dr. Stanko Sielski was a dynamic Bosnian doctor whose interest in rural public health put him in a unique, but dangerous situation during World War II. He not only fulfilled his duty in helping impoverished rural War stricken Bosnians, but he also used his position as Director of the Institute for Combating Endemic Syphilis to shield Jewish physicians working under him. From the envelope covers extant, we show that some of Dr. Stanko Sielski's correspondences with Jewish physicians were being monitored, and that this activity may have begun during the later War years. We hope this paper can add to the understanding of European public health institute censorship during World War II. More scholarship in this area is needed and more on the dynamic figure of Dr. Stanko Sielski is forthcoming.

\section{What is already known on this topic}

Civil and military institutions are targets of censorship during times of war. There is less known about censorship of public health institutions during times of armed conflict. Data on 
postal censorship of European public health institutes during the Second World War are insufficient.

\section{What this study adds}

This paper adds to the understanding of European public health institute censorship during World War II. While the data is limited, it suggests that censorship of these institutes may have occurred later in the war, and as a result, certain institutes were used to shield Jewish physicians from the Holocaust.

Authors' contributions: Conception and design: JP and HT; Acquisition, analysis and interpretation of data: JP and HT; Drafting the article: JP and HT; Revising it critically for important intellectual content: HT and JP; Approved final version of the manuscript: $\mathrm{JP}$ and $\mathrm{HT}$.

Conflict of interest: The authors declare that they have no conflict of interest.

\section{References}

1. The Miroslav Krleža Institute of Lexicography [homepage on the Internet]. Zagreb: the Independent State of Croatia [in Croatian]. [updated 2013 December 29; cited 2015 October 12].

Available from: http://www.enciklopedija.hr/natuknica.aspx? $\mathrm{ID}=43670$.

2. Promitzer C, Troumpeta S, Turda M, Central European University. Health, hygiene, and eugenics in southeastern Europe to 1945. Budapest; New York: Central European University Press; 2011. pp. vii, 466.
3. The statutory provisions on the establishment of the Institute for combating endemic syphilis. In: Junašević J, Šantek M, editors. Proceedings of the laws and orders of the Independent State of Croatia [in Croatian]. Zagreb: Hrvatska državna tiskara; 1941. p. 217-9.

4. Tahirović H. Dr. Stanko Sielski (1891-1958): Physician, scientist, humanist. Acta Med Acad. 2015;44(2):169-80.

5. Stich HF, Stich W, Specht J. Civil and military censorship during World War II: postal history. Vancouver, B.C.: H.F. Stich; 1993. p. 225.

6. Sielski, Stanko. Postal covers from 1942-44. Private collection of John Papalas.

7. Fatović-Ferenčić S, Tahirović $H$. Foundation of the museum for the history of health in 1944 and role of its first curator Stanko Sielski [in Croatian]. Lijec Vjesn. 2015;137(11-12):377-85.

8. Danon J, Stošić V. Memoars on Holocaust of the Jews from Bosanska Krajina. Banja Luka: The Jewis community of Banja Luka; 2010. [cited 2016 July 15]. Available from: http://www. jobl.org/publikacije/MEMOARS\%20ON\%20 HOLOCAUST\%20OF\%20THE\%20JEWS\%20 FROM\%20BOSANSKA\%20KRAJINA.pdf.

9. Archives of Hospital for Nerve and Mental Diseases "Vrapče" Zagreb. Medical history of Dr. Emil Reich from February 5, 1944 to March 8, 1944.

10. Halioua B, Ichou A, Haiat R, Prasquier R. Righteous Among the Nations: doctors and medical students. BMJ. 2014;349:g7657. 